\title{
Analysis of Soil Microbial Communities Formed by Different Upland Fields in Gyeongnam Province
}

\author{
Min Keun Kim, Yong Sik Ok ${ }^{1}$, Jae-Young Heo, Si-Lim Choi, Sang-Dae Lee, Hyun-Yul Shin, \\ Je-Hong Kim, Hye Ran $\mathrm{Kim}^{2} * *$, and Young Han Lee* \\ Gyeongsangnam-do Agricultural Research and Extension Services, Jinju 660-370, Republic of Korea \\ ${ }^{1}$ Biochar Research Center, Department of Biological Environment, Kangwon National University, \\ Chuncheon 200-701, Republic of Korea \\ ${ }^{2}$ Korea Research Institute of Bioscience and Biotechnology, Daejeon 305-806, Republic of Korea
}

(Received: March 18 2014, Accepted: April 7 2014)

\begin{abstract}
The present study investigated variations in soil microbial communities by fatty acid methyl ester(FAME) and the chemical properties at 24 sites of upland soils in Gyeongnam Province. The electrical conductivity of the soil under potato cultivation was significantly higher than those of the red pepper and soybean soils $(p<0.05)$. The gram-negative bacteria community in potato soil was significantly lower than those in the garlic and soybean soils $(p<0.05)$. The communities of actinomycetes and arbuscular myconhizal fungi in the red pepper soil were significantly higher than those in the potato soil $(p<0.05)$. In addition, the cy17:0 to 16:1 $\omega 7 \mathrm{c}$ ratio was significantly lower in red pepper, soybean, and garlic soils compared with potato soil, indicating that microbial stress decreased. Consequently, differences in soil microbial community were highly associated with cultivated crop species, and this might be resulted from the difference in soil chemical properties.
\end{abstract}

Key words: Soil microbial community, Upland soil, Gram-negative bacteria, FAME

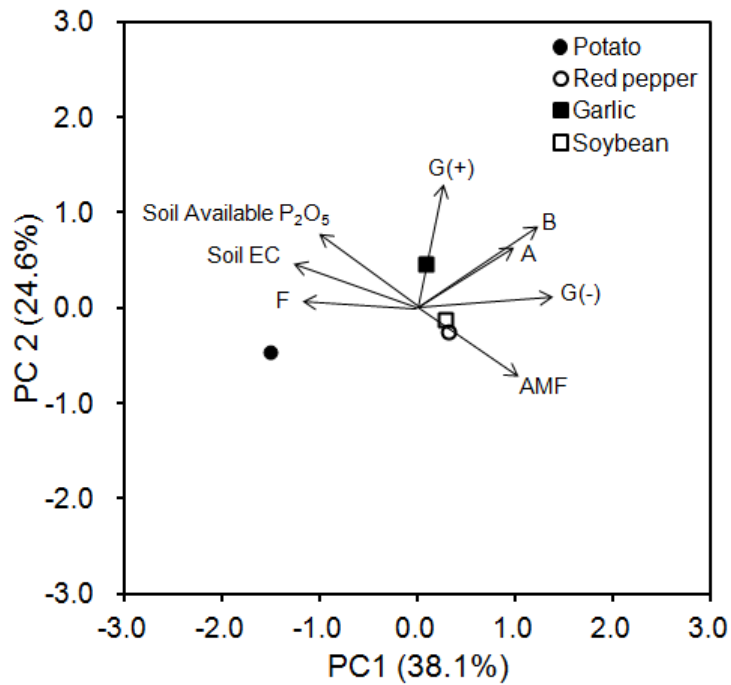

Principal component analyses between microbial communities and chemical properties of different upland soils in Gyeongnam Province. A, actinomycetes; AMF, arbuscular myconhizal fungi; B, total bacteria; EC, electrical conductivity; F, fungi; G(-), gram-negative bacteria; $G(+)$, gram-positive bacteria.

\footnotetext{
*Corresponding author : Phone: +82552541313, E-mail: lyh2011@korea.kr

**Co-Corresponding author : Phone: +821020777133, E-mail: kimhr@kribb.re.kr

$\dagger$ The first two authors equally contributed to this work.

${ }^{\S}$ Acknowledgement: This study was conducted with the support of the Research Cooperating Program for Agricultural Science \& Technology Development (Project No. PJ009198252014), RDA, Republic of Korea.
} 


\section{Introduction}

토양의 양분 불균형은 작물의 생육을 저해하는 요인이며 미생물 생태계를 교란시키기 때문에 지속가능한 친환경농 업을 위해서는 적정한 토양 양분관리를 통한 미생물의 활 성을 증대시키는 것이 필요하다 (Lee and Kim, 2011; Lee and Yun, 2011). 예전에는 토양의 미생물을 평가할 때 선 택배지를 이용하였으나 현재에는 신뢰도를 높이기 위해 미 생물의 지방산 조성을 분석하거나 (Kim and Lee, 2011; Macalady et al., 1998; Schutter and Dick, 2000) DNA 를 추출하여 분석하는 파이로시컨싱 기술을 사용하고 있다 (Davinic et al., 2012; Jones et al., 2009). 토양 미생 물은 양분, 작물, 기상조건 등 주변 환경에 민감하게 반응 하며 최종적으로 환경에 생존하는 미생물이 우점하게 된 다. 따라서 건강한 농업 생태계를 유지하기 위해서는 토양 비옥도 뿐만 아니라 토양 미생물의 다양성을 함께 검토해 야 한다. 경남지역의 지형별 밭토양의 곰팡이 개체수는 곡 간 및 선상지가 하성평탄지 보다 많았고 토양 미생물체량 과 탈수소효소 활성은 산록경사지가 높았다. 바실러스균과 곰팡이균은 토양의 유기물 함량과 정의 상관관계를 보였고
토양 $\mathrm{pH}$ 는 형광성 슈도모나스균과 정의 상관관계가 있는 것으로 알려져 있다 (Lee and Ha, 2011a). 또한, 토성에 따라 미사질양토는 방선균 군집이 $2.2 \%$ 로 사양토 $1.8 \%$ 에 비해 높았으며 곰팡이 군집은 사양토에서 $20.4 \%$ 로 양토 $16.4 \%$ 와 미사질양토 $15.4 \%$ 에 비해 높은 것으로 보고되었 다 (Lee and $\mathrm{Ha}, 2011 \mathrm{~b})$. 그러나 밭토양에서 작물별 토 양 미생물의 군집에 대한 연구는 미미하며 토양 생태계 관 리를 위한 기초적인 자료 확보가 시급한 실정이다.

본 연구는 경남지역 밭토양 24개소를 대상으로 2013년 에 토양의 화학성과 세포벽 지방산 함량을 분석하여 미생 물 군집을 검토하였으며 주성분 분석에 의한 작물별 주요 변동요인을 구명하여 친환경 토양관리를 위한 기초 자료를 제공코자 수행하였다.

\section{Materials and Methods}

밭토양 지점 선정 및 시료채취 방법 경남지역 밭토 양의 화학성분과 미생물 군집의 상관관계를 분석하기 위하 여 2013년에 감자 재배지 3 개소, 고추 재배지 4개소, 마늘 재배지 8 개소, 콩 재배지 9 개소 등 24 개소를 선정하였다

Table 1. Upland soil sampling sites from different locations in Gyeongnam Province ( $n=24)$.

\begin{tabular}{|c|c|c|c|c|c|}
\hline Region & Crop & Soil texture & Land form & Longitude & Latitude \\
\hline Jinju & Red pepper & Loam & Hill & $128^{\circ} 1^{\prime} 36.74^{\prime \prime}$ & $35^{\circ} 8^{\prime} 33.49^{\prime \prime}$ \\
\hline Jinju & Potato & Loam & Valley & $128^{\circ} 2^{\prime} 12.31^{\prime \prime}$ & $35^{\circ} 11^{\prime} 25.86^{\prime \prime}$ \\
\hline Sacheon & Soybean & Loam & Mountain foot-slope & $128^{\circ} 8^{\prime} 29.05^{\prime \prime}$ & $34^{\circ} 59^{\prime} 50.55^{\prime \prime}$ \\
\hline Sacheon & Garlic & Loam & Hill & $128^{\circ} 6^{\prime} 46.80^{\prime \prime}$ & $34^{\circ} 55^{\prime} 46.53^{\prime \prime}$ \\
\hline Kimhae & Soybean & Loam & Mountain foot-slope & $128^{\circ} 48^{\prime} 51.41^{\prime \prime}$ & $35^{\circ} 17^{\prime} 58.37^{\prime \prime}$ \\
\hline Geoje & Garlic & Loam & Mountain foot-slope & $128^{\circ} 30^{\prime} 35.09^{\prime \prime}$ & $34^{\circ} 50^{\prime} 32.13^{\prime \prime}$ \\
\hline Yangsan & Garlic & Loam & Alluvial fan & $128^{\circ} 56^{\prime} 38.68^{\prime \prime}$ & $35^{\circ} 20^{\prime} 48.31^{\prime \prime}$ \\
\hline Uiryeong & Red pepper & Silt loam & Valley & $128^{\circ} 19^{\prime} 56.86^{\prime \prime}$ & $35^{\circ} 24^{\prime} 2.16^{\prime \prime}$ \\
\hline Uiryeong & Soybean & Loamy sand & Alluvial plain & $128^{\circ} 12^{\prime} 03.08^{\prime \prime}$ & $35^{\circ} 19^{\prime} 59.61^{\prime \prime}$ \\
\hline Haman & Soybean & Silt loam & Hill & $128^{\circ} 22^{\prime} 48.23^{\prime \prime}$ & $35^{\circ} 16^{\prime} 7.70^{\prime \prime}$ \\
\hline Haman & Garlic & Loam & Mountain foot-slope & $128^{\circ} 25^{\prime} 50.24^{\prime \prime}$ & $35^{\circ} 13^{\prime} 0.10^{\prime \prime}$ \\
\hline Changnyeong & Potato & Silt loam & Alluvial plain & $128^{\circ} 35^{\prime} 56.57^{\prime \prime}$ & $35^{\circ} 23^{\prime} 48.74^{\prime \prime}$ \\
\hline Goseong & Soybean & Loam & Valley & $128^{\circ} 12^{\prime} 42.05^{\prime \prime}$ & $34^{\circ} 59^{\prime} 43.35^{\prime \prime}$ \\
\hline Namhae & Potato & Loam & Hill & $127^{\circ} 53^{\prime} 12.11^{\prime \prime}$ & $34^{\circ} 52^{\prime} 56.00^{\prime \prime}$ \\
\hline Hadong & Garlic & Loam & Mountain foot-slope & $127^{\circ} 54^{\prime} 4.83^{\prime \prime}$ & $35^{\circ} 7^{\prime} 3.08^{\prime \prime}$ \\
\hline Sancheong & Garlic & Loam & Valley & $127^{\circ} 53^{\prime} 27.65^{\prime \prime}$ & $35^{\circ} 24^{\prime} 50.90^{\prime \prime}$ \\
\hline Sancheong & Soybean & Loam & Hill & $127^{\circ} 56^{\prime} 57.84^{\prime \prime}$ & $35^{\circ} 19^{\prime} 40.79^{\prime \prime}$ \\
\hline Hamyang & Soybean & Sandy loam & Valley & $127^{\circ} 47^{\prime} 6.04^{\prime \prime}$ & $35^{\circ} 34^{\prime} 1.95^{\prime \prime}$ \\
\hline Hamyang & Soybean & Sandy loam & Valley & $127^{\circ} 47^{\prime} 4.29^{\prime \prime}$ & $35^{\circ} 32^{\prime} 3.38^{\prime \prime}$ \\
\hline Geochang & Garlic & Loam & Valley & $127^{\circ} 56^{\prime} 16.98^{\prime \prime}$ & $35^{\circ} 39^{\prime} 5.14^{\prime \prime}$ \\
\hline Geochang & Red pepper & Sandy loam & Valley & $127^{\circ} 51^{\prime} 1.14^{\prime \prime}$ & $35^{\circ} 41^{\prime} 39.81^{\prime \prime}$ \\
\hline Hapcheon & Soybean & Silty clay loam & Hill & $128^{\circ} 9^{\prime} 15.62^{\prime \prime}$ & $35^{\circ} 29^{\prime} 41.86^{\prime \prime}$ \\
\hline Hapcheon & Red pepper & Silt loam & Valley & $128^{\circ} 7^{\prime} 51.07^{\prime \prime}$ & $35^{\circ} 25^{\prime} 2.24^{\prime \prime}$ \\
\hline Ulsan & Garlic & Loam & Hill & $129^{\circ} 8^{\prime} 42.45^{\prime \prime}$ & $35^{\circ} 36^{\prime} 35.81^{\prime \prime}$ \\
\hline
\end{tabular}


(Table 1). 토양은 비료를 시용하기 전인 3월부터 4 월 사 이에 표토를 $1 \mathrm{~cm}$ 정도 걷어내고 0-15 cm 깊이에서 500 $\mathrm{g}$ 정도를 3 반복으로 채취하였다.

\section{시료조제 및 화학성분 분석방법 작물별로 채취한} 토양은 그늘진 곳에서 7일간 건조한 후 $2 \mathrm{~mm}$ 체를 통과 된 것을 화학성분 분석에 사용하였다. 토양의 화학성분은 농촌진흥청 국립농업과학원 토양 화학 분석법 (NIAST, 2010a) 을 적용하여 $\mathrm{pH}$ 와 $\mathrm{EC}$ 는 토양과 증류수의 비율을 $1: 5$ 로 희 석한 후 $\mathrm{pH}$ meter (Orion 520A pH meter, Orion Research Inc., Boston, USA)와, EC meter (Orion 3STAR EC meter, Orion Research Inc., Boston, USA)로 분석하였다. 유 기물은 Tyurin법, 유효인산은 Lancaster 법으로 비색계 (UV-1650PC, Shimadzu Co., Kyoto, Japan)를 사용 하여 분석하였다. 치환성 칼륨, 칼슘, 마그네슘, 나트륨 등 의 양이온은 $1 \mathrm{M} \mathrm{NH} \mathrm{NH}_{4} \mathrm{OAc}$ 로 추출하여 적당량 희석한 후 ICP (AAnalyst 300, Perkin-Elmer, Norwalk, USA) 로 분석하였다.

미생물 군집 분석 밭토양 미생물 군집은 습토를 냉동 실에 보관하면서 분석하였다. 미생물 군집은 미생물이 가 지고 있는 고유 세포벽 지방산을 분석하는 fatty acid methyl ester (FAME) 방법을 이용하였다 (Schutter and Dick, 2000). 미생물의 군집 분석은 GC Agilent 6890N (Agilent Technologies, USA)과 HP-ULTRA 2 capillary column $(25 \mathrm{~m} \times 0.2 \mathrm{~mm} \times 0.33 \mu \mathrm{m}$ film thickness, Agilent Technologies, USA)을 이용하였고 미생물 정량은 내부 표준 지방산 (19:0)을 이용하여 상대적인 비율을 계산하였 다. 분석된 지방산 조성은 MIDI software program package (MIDI, Inc., Newark, DE)을 이용하여 미생물 군집으로 분석하였다 (Hamel et al., 2006). 총 세균은 관련된 지

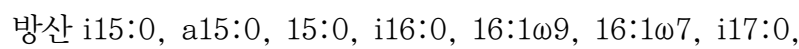
$\mathrm{a} 17: 0,17: 0, \mathrm{cy} 17: 0,18: 1 \omega 7 \mathrm{c}$ 및 cy19:0을 합산하여 분 석하였다 (Macalady et al., 1998; Schutter and Dick,
2000). 그람음성 세균은 지방산 $16: 1 \omega 7 \mathrm{c}, 18: 1 \omega 7 \mathrm{c}$, су17:0 및 cy19:0을 합산하였고 그람양성 세균은 지방산 i15:0, a15:0, i16:0, i17:0 및 a17:0을 합산하여 구하였다 (Zelles, 1997). 방선균은 지방산 10Me18:0을 사용하였고 (Schutter and Dick, 2000) 곰팡이는 지방산 $18: 1 \omega 9 \mathrm{c}$ 와 $18: 2 \omega 6 \mathrm{c}$ 를 사용하였다 (Bradleya et al., 2006). 또한, 지방산 16:1 $\omega 5 \mathrm{c}$ 는 arbuscular mycorrhizal fungi의 biomarker로 이용하였다 (Balser et al., 2005; Frostegård et al., 1993; Olsson et al., 1998). 그리고 곰팡이와 총 세균의 비율을 조사하였고 지방산 cy17:0과 $16: 1 \mathrm{w} 7 \mathrm{c}$ 의 비율은 미생물의 스트레스 지표로 사용하였다 (Guckert et al., 1986; Grogan and Cronan, 1997).

다변량 주성분 분석 및 통계분석 분석된 토양 화학 성과 미생물 군집은 SAS 프로그램 (버젼 9.1.3, 2006)을 사용하여 통계분석 하였다. 작물별 토양 미생물 특성과 화 학성은 5\% 수준에서 Tukey's studentized range test를 하였다. 그리고 토양 $\mathrm{EC}$ 와 유효인산 함량 및 미생물 군집 은 주성분 분석을 통하여 작물 재배지에 따른 차이를 비교 검토하였다.

\section{Results and Discussion}

밭토양 화학성 분석결과 경남지역 미생물 군집을 분 석하기 위한 밭토양의 화학성분의 분석결과는 Table 2 와 같다. 밭토양의 $\mathrm{pH}$ 는 고추 재배지가 6.9 로서 감자 재배지 5.7 보다 유의적으로 높은 반면 $(p<0.05)$ 염류농도는 감 자 재배지가 $1.66 \mathrm{dS} \mathrm{m}^{-1}$ 로 콩 재배지 $0.54 \mathrm{dS} \mathrm{m}^{-1}$ 및 고추 재배지 $0.50 \mathrm{dS} \mathrm{m}^{-1}$ 보다 유의적으로 높았다 ( $p$ < 0.05). 치환성 칼륨과 치환성 칼슘 함량은 마늘 재배지가 $1.34 \mathrm{cmol}_{\mathrm{c} \mathrm{kg}} \mathrm{kg}^{-1}$ 및 $10.0 \mathrm{cmol}_{\mathrm{c}} \mathrm{kg}^{-1}$ 으로서 고추 재배지 칼륨 함량인 $0.48 \mathrm{cmol}_{\mathrm{c} \mathrm{kg}}$ 와 감자 재배지 칼슘 함량인 $4.1 \mathrm{cmol}_{\mathrm{c}} \mathrm{kg}^{-1}$ 보다 유의적으로 높았다 $(p<0.05)$. 밭토 양의 유기물, 유효인산, 치환성 마그네슘 및 치환성 나트

Table 2. Chemical properties of upland soils in Gyeongnam Province as affected by different crops.

\begin{tabular}{|c|c|c|c|c|c|c|c|c|c|}
\hline \multirow{2}{*}{ Crop } & \multirow{2}{*}{$\mathrm{pH}$} & \multirow{2}{*}{$\mathrm{EC}$} & \multirow{2}{*}{$\mathrm{OM}$} & \multirow{2}{*}{ Avail. $\mathrm{P}_{2} \mathrm{O}_{5}$} & \multicolumn{4}{|c|}{ Exch. cation } & \multirow{2}{*}{ Site } \\
\hline & & & & & $\mathrm{K}$ & $\mathrm{Ca}$ & $\mathrm{Mg}$ & $\mathrm{Na}$ & \\
\hline & $(1: 5)$ & $\mathrm{dS} \mathrm{m}^{-1}$ & $\mathrm{~g} \mathrm{~kg}^{-1}$ & $\mathrm{mg} \mathrm{kg}{ }^{-1}$ & \multicolumn{4}{|c|}{ - } & No. \\
\hline Potato & $5.7 \mathrm{~b}^{\dagger}$ & $1.66 \mathrm{a}$ & $18 \mathrm{a}$ & $945 \mathrm{a}$ & $0.94 \mathrm{ab}$ & $4.1 \mathrm{~b}$ & $1.2 \mathrm{a}$ & $0.34 \mathrm{a}$ & 3 \\
\hline Red pepper & $6.9 \mathrm{a}$ & $0.50 \mathrm{~b}$ & $20 \mathrm{a}$ & $742 \mathrm{a}$ & $0.48 b$ & $5.6 \mathrm{ab}$ & $1.7 \mathrm{a}$ & $0.28 \mathrm{a}$ & 4 \\
\hline Garlic & $6.7 \mathrm{ab}$ & $1.17 \mathrm{ab}$ & $28 \mathrm{a}$ & $885 \mathrm{a}$ & $1.34 \mathrm{a}$ & $10.0 \mathrm{a}$ & $2.2 \mathrm{a}$ & $0.38 \mathrm{a}$ & 8 \\
\hline Soybean & $6.3 \mathrm{ab}$ & $0.54 b$ & $31 \mathrm{a}$ & $610 \mathrm{a}$ & $0.69 \mathrm{ab}$ & 7.6ab & $1.5 \mathrm{a}$ & $0.34 \mathrm{a}$ & 9 \\
\hline Average & 6.5 & 0.89 & 27 & 766 & 0.90 & 7.6 & 1.7 & 0.34 & 24 \\
\hline
\end{tabular}

${ }^{\dagger}$ Means by the same letter within a column are not significantly different at 0.05 probability level according to Tukey's studentized range test. 
Table 3. Microbial biomass of upland soils in Gyeongnam Province as affected by different crops.

\begin{tabular}{|c|c|c|c|c|c|c|c|c|c|}
\hline Crop & $\mathrm{TF}^{\dagger}$ & B & G(-) & $\mathrm{G}(+)$ & $\mathrm{A}$ & $F$ & AMF & $\mathrm{G}(-) / \mathrm{G}(+)$ & F/B \\
\hline & \multicolumn{9}{|c|}{-- } \\
\hline Potato & $299 a^{\ddagger}$ & $70.7 \mathrm{a}$ & $30.1 \mathrm{a}$ & $36.0 \mathrm{a}$ & $3.8 \mathrm{a}$ & $72.0 \mathrm{a}$ & $3.4 \mathrm{a}$ & $0.84 a$ & $1.02 \mathrm{a}$ \\
\hline Red pepper & $195 \mathrm{a}$ & $52.6 \mathrm{a}$ & $24.7 \mathrm{a}$ & $24.3 \mathrm{a}$ & $3.7 \mathrm{a}$ & $30.0 \mathrm{a}$ & $5.4 \mathrm{a}$ & $1.02 \mathrm{a}$ & $0.57 \mathrm{~b}$ \\
\hline Garlic & $341 \mathrm{a}$ & $97.3 \mathrm{a}$ & $46.4 \mathrm{a}$ & $44.2 \mathrm{a}$ & $6.4 \mathrm{a}$ & $62.0 \mathrm{a}$ & $8.9 \mathrm{a}$ & $1.05 \mathrm{a}$ & $0.64 \mathrm{ab}$ \\
\hline Soybean & $302 a$ & $85.9 \mathrm{a}$ & $41.4 \mathrm{a}$ & $39.1 \mathrm{a}$ & $5.2 \mathrm{a}$ & $47.9 a$ & $6.9 \mathrm{a}$ & $1.06 \mathrm{a}$ & $0.56 \mathrm{~b}$ \\
\hline Average & 297 & 82.3 & 38.9 & 37.9 & 5.2 & 52.6 & 6.9 & 1.03 & 0.62 \\
\hline
\end{tabular}

${ }^{\dagger}$ TF, total FAMEs; B, total bacteria; G(-), gram-negative bacteria; G(+), gram-positive bacteria; A, actinomycetes; F, fungi; AMF, arbuscular mycorrhizal fungi.

${ }^{\ddagger}$ Means by the same letter within a column are not significantly different at 0.05 probability level according to Tukey's studentized range test.

륨 함량은 작물별로 유의적인 차이가 없었다. 밭토양 화학 성분의 평균값은 $\mathrm{pH} 6.5$, 염류농도 $0.89 \mathrm{dS} \mathrm{m}^{-1}$, 유기물 27 , 유효인산 $766 \mathrm{mg} \mathrm{kg}^{-1}$, 치환성 칼륨 $0.90 \mathrm{cmol}_{\mathrm{c}}$ $\mathrm{kg}^{-1}$, 치환성 칼슘 $7.6 \mathrm{cmol}_{\mathrm{c}} \mathrm{kg}^{-1}$, 치환성 마그네슘 1.7 $\mathrm{cmol}_{\mathrm{c}} \mathrm{kg}^{-1}$, 치환성 나트륨 $0.34 \mathrm{cmol}_{\mathrm{c}} \mathrm{kg}^{-1}$ 로서 밭토양 적정수준 (NIAST, 2010b) 보다 유효인산, 치환성 칼륨 및 치환성 칼슘 함량이 높았다. 이러한 결과는 Lee and $\mathrm{Ha}$ (2011a)가 보고한 결과와 일치하였다.

\section{밭토양 미생물 함량 비교 경남지역 밭토양의 미생물} 함량은 Table 3 과 같다. 밭토양 24 개소의 평균값은 총 FAME 함량이 $297 \mathrm{nmol} \mathrm{g^{-1 }}$ 이었으며 총 세균 함량은 $82.3 \mathrm{nmol} \mathrm{g}^{-1}$, 그람음성 세균 함량은 $38.9 \mathrm{nmol} \mathrm{g}^{-1}$, 그림양성 세균은 $37.9 \mathrm{nmol} \mathrm{g}^{-1}$, 방선균 함량은 $5.2 \mathrm{nmol} \mathrm{g}^{-1}$, 곰팡이 함량은 $52.6 \mathrm{nmol} \mathrm{g}^{-1}$, 내생균근균 함량은 6.9 $\mathrm{nmol} \mathrm{g}{ }^{-1}$ 이었다. 이러한 결과는 Lee and $\mathrm{Ha}$ (2011b)가 보고한 경남지역 밭토양 25 개소의 평균값인 총 $\mathrm{FAME}$ 함 량 $238 \mathrm{nmol} \mathrm{g}^{-1}$, 총 세균 $73 \mathrm{nmol} \mathrm{g}$, 그람음성 세균 과 그람양성 세균은 $33 \mathrm{nmol} \mathrm{g}^{-1}$, 방선균 $4.5 \mathrm{nmol} \mathrm{g}^{-1}$, 곰팡이 $40 \mathrm{nmol} \mathrm{g}^{-1}$, 내생균근균 $6.8 \mathrm{nmol} \mathrm{g}^{-1}$ 보다 약 간 높았다. 따라서 경남지역 밭토양의 미생물 함량은 2013 년에 약간 증가되는 것으로 나타났으며 미생물의 분류에 따른 함량은 크게 변화가 없는 것으로 판단된다. 경남지역 밭토양의 미생물 함량은 시설 재배지에 비해 세균과 곰팡 이 함량은 낮았고 (Lee et al., 2011) 논에서 벼 생육초기 토양에 비해 세균 함량은 낮고 곰팡이 함량은 높았다 (Kim and Lee, 2011). 그리고 그람음성 세균과 그람양성 세균 비율은 1.03 으로 논에서 벼 생육초기 토양의 1.0-1.3과 비 슷하였다 (Kim and Lee, 2011). 일반적으로 그람음성 세 균은 토양에서 미생물의 영양분이 부족할 경우 개체수가 감소하는데 이러한 결과로 볼 때 경남지역 밭토양의 양분 상태는 양호한 것으로 생각된다 (Kieft et al., 1997).

작물 재배지별 미생물 함량은 마늘 재배지에서 총 FAME
함량이 $341 \mathrm{nmol} \mathrm{g}^{-1}$, 총 세균 함량이 $97.3 \mathrm{nmol} \mathrm{g}^{-1}$, 그 람음성 세균 $46.4 \mathrm{nmol} \mathrm{g}^{-1}$, 그람양성 세균 $44.2 \mathrm{nmol} \mathrm{g}^{-1}$, 방선균 $6.4 \mathrm{nmol} \mathrm{g}^{-1}$, 내생균근균 $8.9 \mathrm{nmol} \mathrm{g}^{-1}$ 으로 다른 작물에 비해 높았으나 유의적인 차이는 없었다. 곰팡이/세 균의 비율은 감자 재배지가 1.02 로 가장 높은 반면 고추 재배지가 0.56 으로 가장 낮은 것으로 나타났다 $(p<0.05)$. 토양 $\mathrm{pH}$ 가 낮았던 감자 재배지에서 곰팡이와 세균의 비율 이 높은 것은 곰팡이가 세균에 비해 대체로 $\mathrm{pH}$ 변화에 대 한 내성이 강하고 토양 $\mathrm{pH}$ 가 낮을수록 곰팡이/세균의 비 율이 증가한다는 연구 결과와 일치하였다 (Rousk et al., 2009; Rousk et al., 2010).

미생물 스트레스 지표 밭토양의 환경과 양분함량에 대한 스트레스 지표로 사용되는 cy17:0과 16:107c 비율은 Fig. 1과 같다. 일반적으로 cy17:0과 $16: 1 \omega 7 \mathrm{c}$ 비율이 낮 을수록 미생물이 받는 스트레스는 감소되는 것으로 알려져 있다 (Mechri et al., 2010). 경남지역 밭토양은 감자 재

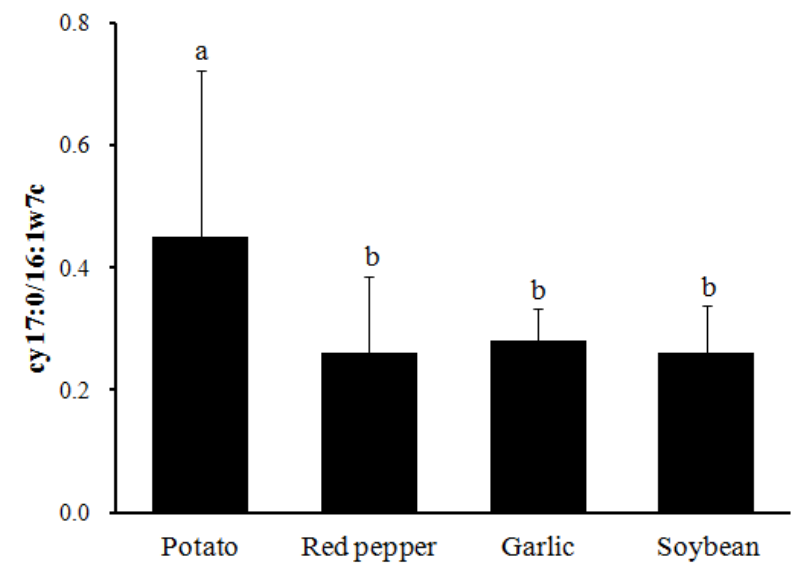

Fig. 1. Ratio of fatty acid cy17:0 to 16:1w7c of different upland soils in Gyeongnam Province. Means by the same letter within a column are not significantly different at $\mathbf{0 . 0 5}$ probability level according to Tukey's studentized range test. Bars represent one standard deviation of the mean. 
Table 4. Microbial communities of upland soils in Gyeongnam Province as affected by different crops.

\begin{tabular}{|c|c|c|c|c|c|c|}
\hline Crop & $\mathrm{B}^{\dagger}$ & $\mathrm{G}(-)$ & $\mathrm{G}(+)$ & $\mathrm{A}$ & F & AMF \\
\hline & \multicolumn{6}{|c|}{ 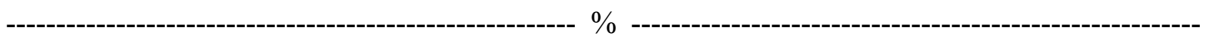 } \\
\hline Potato & $24.3 b^{\ddagger}$ & $10.9 \mathrm{~b}$ & $12.0 \mathrm{a}$ & $1.3 b$ & $20.0 \mathrm{a}$ & $1.1 \mathrm{~b}$ \\
\hline Red pepper & $27.3 \mathrm{a}$ & $13.0 \mathrm{ab}$ & $12.5 \mathrm{a}$ & $2.0 \mathrm{a}$ & $15.2 \mathrm{a}$ & $2.9 \mathrm{a}$ \\
\hline Garlic & $28.8 \mathrm{a}$ & $13.7 \mathrm{a}$ & $13.1 \mathrm{a}$ & $1.8 \mathrm{ab}$ & $18.0 \mathrm{a}$ & $2.5 \mathrm{ab}$ \\
\hline Soybean & $27.8 \mathrm{a}$ & $13.4 \mathrm{a}$ & $12.8 \mathrm{a}$ & $1.7 \mathrm{ab}$ & $15.6 \mathrm{a}$ & $2.3 \mathrm{ab}$ \\
\hline Average & 27.6 & 13.1 & 12.8 & 1.8 & 16.9 & 2.3 \\
\hline
\end{tabular}

${ }^{\dagger} \mathrm{B}$, total bacteria; $\mathrm{G}(-)$, gram-negative bacteria; $\mathrm{G}(+)$, gram-positive bacteria; A, actinomycetes; $\mathrm{F}$, fungi; AMF, arbuscular mycorrhizal fungi.

${ }^{\ddagger}$ Means by the same letter within a column are not significantly different at 0.05 probability level according to Tukey's studentized range test.

배지가 0.45 로서 마늘 재배지 0.28 , 고추 및 콩 재배지 0.26 보다 유의적으로 높았다 $(p<0.05)$. 이러한 경향은 Table 2 와 같이 감자 재배지는 산성 토양에 유기물이 부 족한 반면 유효인산 함량은 높아 세균의 스트레스가 증가 된 것으로 생각되었다 (Bossio and Scow. 1998).

밭토양 미생물 군집 분석 밭토양 미생물의 함량을 총 FAME 함량으로 나누어 각 미생물의 군집을 분석한 결 과는 Table 4 와 같다. 밭토양 평균 미생물 군집은 총 세균 이 $27.6 \%$, 곰팡이 $16.9 \%$, 그람음성 세균은 $13.1 \%$, 그람양 성 세균은 $12.8 \%$, 내생균근균 $2.3 \%$, 방선균 $1.8 \%$ 의 비율 을 나타냈다. 이러한 결과는 Lee and $\mathrm{Ha}$ (2011b)가 보고 한 경남지역 밭토양 평균 미생물 군집 보다 총 세균은 $2.7 \%$, 곰팡이는 $0.5 \%$ 낮은 경향이었다. 경남지역 밭토양의 작물 별 총 세균 군집은 마늘 재배지 $28.8 \%$, 콩 재배지 $27.8 \%$, 고추 재배지가 $27.3 \%$ 로서 감자 재배지 $24.3 \%$ 보다 유의 적으로 많았다 $(p<0.05)$. 이러한 경향은 그람음성 세균 의 군집이 크게 영향을 미친 것으로 나타났다. Kieft et al. (1997)이 보고한 바에 따르면 그람음성 세균은 토양에 서 미생물의 영양분이 부족할 경우 분포비율이 감소하게 되는데 본 연구에서는 Table 2 와 같이 감자 재배지의 유 기물 함량이 낮아 그람음성 세균의 분포에 영향을 미친 것 으로 생각된다. 그리고 방선균과 내생균근균의 군집은 고 추 재배지가 각각 $2.0 \%$ 및 $2.9 \%$ 로서 감자 재배지의 $1.3 \%$ 와 $1.1 \%$ 에 비해 유의적으로 많은 것으로 나타났으며 ( $p$ < $0.05)$ Lee and $\mathrm{Ha}$ (2011b)가 보고한 결과와 일치하였다. 이러한 결과는 감자 재배지의 유기물 부족과 관련된 것으 로 생각된다.

경남지역 밭토양의 미생물 군집과 토양 염류농도와 유효 인산 함량을 포함한 작물 재배지별 주성분 분석결과는 Fig. 2 와 같다. 여러 가지 요인을 주성분으로 분석한 결과 는 토양 미생물 군집을 간단하게 설명하고 예측할 수 있다 (Lee et al., 2011; Yang et al., 2012). 주성분 분석결

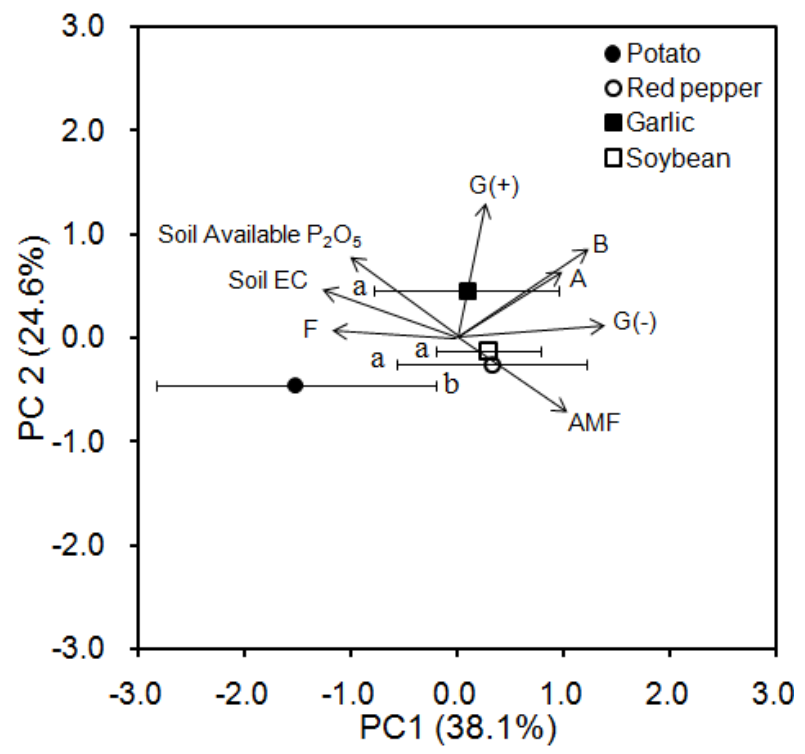

Fig. 2. Principal component analyses between microbial communities and chemical properties of different upland soils in Gyeongnam Province. The variance explained by each principal component (PC) axis is shown in parentheses. PC analysis shows loading values for the individual microbial biomarkers. The bars represent one standard deviation of the mean. Means by the same letter within a column are not significantly different at $\mathbf{0 . 0 5}$ probability level according to Tukey's studentized range test. A, actinomycetes; AMF, arbuscular myconhizal fungi; B, total bacteria; EC, electrical conductivity; F, fungi; G(-), gram-negative bacteria; $\mathbf{G}(+)$, gram-positive bacteria.

과 제 1 주성분이 $38.1 \%$, 제 2 주성분이 $24.6 \%$ 로서 전체 $62.7 \%$ 의 자료를 설명할 수 있는 것으로 나타났다. 제 1 주성분은 그람음성 세균 군집(0.455), 곰팡이군집 $(-0.380)$ 과 토양 염류농도 $(-0.408)$ 가 제 2 주성분은 그람양성 세균 $(0.627)$ 이 주로 관련된 것으로 나타났으며, 통 세균 군집 (0.428) 과 방선균 군집은 제 1 주성분 및 제 2 주성분에 모두 관여하 는 것으로 나타났다. 작물 재배지별 주성분 분석결과 감자 
재배지는 제 1 주성분에서 고추 재배지, 마늘 재배지 및 콩 재배지에 비해 유의적으로 낮았다 $(p<0.05)$. 그러나 제 2 주성분은 작물 재배지별로 유의성 있는 차이가 없었다.

\section{Conclusions}

경남지역 밭토양 24개소를 대상으로 2013년에 미생물 세포벽 지방산 함량을 분석하여 작물별 미생물 군집을 주 성분 분석으로 해석하였다. 경남지역 밭토양은 감자 재배 지는 유기물 함량이 $18 \mathrm{~g} \mathrm{~kg}^{-1}$ 으로 부족한 토양으로 지방 산 cy17:0과 $16: 1 \omega 7 \mathrm{c}$ 비율이 0.45로서 마늘 재배지 0.28, 고추 및 콩 재배지 0.26 보다 유의적으로 높아 미생물이 받는 스트레스는 큰 것으로 나타났으며 그람음성 세균의 군집도 $10.9 \%$ 로 마늘 재배지 $13.7 \%$ 와 콩 재배지 $13.4 \%$ 에 비해 낮았다. 미생물 군집의 주성분 분석결과 제 1 주성분이 $38.1 \%$, 제 2 주성분이 $24.6 \%$ 로서 전체 $62.7 \%$ 의 자료를 설 명할 수 있었으며 그람음성 세균의 군집이 가장 크게 영향 을 주는 것으로 나타났다. 토양에서 미생물 군집의 변화는 토양환경과 복잡한 관계를 형성하고 있기 때문에 유기물 함량을 높이고 $\mathrm{pH}$ 를 적정범위로 유지하는 것이 무엇보다 중요하며 환경변화에 따른 미생물 변동에 대해 지속적으로 모니터링이 필요할 것이다.

\section{References}

Balser, T., K.K. Treseder, and M. Ekenler. 2005. Using lipid analysis and hyphal length to quantify AM and saprotrophic fungal abundance along a soil chronosequence. Soil Biol. Biochem. 37:601-604.

Bossio, D.A. and K.M. Scow. 1998. Impacts of carbon and flooding on soil microbial communities: phospholipid fatty acid profiles and substrate utilization patterns. Microb. Ecol. 35:265-278.

Bradleya, K., A. Rhae, R.A. Drijberb, and J. Knopsc. 2006. Increased $\mathrm{N}$ availability in grassland soils modifies their microbial communities and decreases the abundance of arbuscular mycorrhizal fungi. Soil Biol. Biochem. 38:1583-1595.

Davinic, M., L.J. Fultz, V. Acosta-Martinez, F.J. Calderón, S.B. Cox, S.E. Dowd, V.G. Allen, J.C. Zak, and J. Moore-Kucera. 2012. Pyrosequencing and mid-infrared spectroscopy reveal distinct aggregate stratification of soil bacterial communities and organic matter composition. Soil Biology and Biochemistry. 46:63-72.

Frostegård, Å., A. Tunlid, and E. Bååth. 1993. Phospholipid fatty acid composition, biomass and activity of microbial communities from two soil types experimentally exposed to different heavy metals. Appl. Environ. Microbiol. 59:3605-3617.

Grogan, D.W. and J.E. Cronan. 1997. Cyclopropane ring formation in membrane lipids of bacteria. Microbiol. Mol. Biol. Rev.
61:429-441.

Guckert, J.B., M.A. Hood, and D.C. White. 1986. Phospholipid ester-linked fatty acid profile changes during nutrient deprivation of Vibrio cholerae: increases in cis/trans ratio and proportions of cyclopropyl fatty acid. Appl. Environ. Microbial. 52:794-801.

Hamel, C., K. Hanson, F. Selles, A.F. Cruz, R. Lemke, B. McConkey, and R. Zentner. 2006. Seasonal and long-term resource-related variations in soil microbial communities in wheat-based rotations of the Canadian prairie. Soil Biol. Biochem. 38:2104-2116.

Jones, R.T., M.S. Robeson, C.L. Lauber, M. Hamady, R. Knight, and N. Fierer. 2009. A comprehensive survey of soil acidobacterial diversity using pyrosequencing and clone library analyses. ISME J. 3:442-453.

Kieft, T.L., E. Wilch, K. O'connor, D.B. Ringelberg, and D.C. White. 1997. Survival and phospholipid fatty acid profiles of surface and subsurface bacteria in natural sediment microcosms. Appl. Environ. Microbiol. 63:1531-1542.

Kim E.S. and Y.H. Lee. 2011. Response of soil microbial communities to applications of green manures in paddy at an early rice growing stage. Korean J. Soil Sci. Fert. 44:221-227.

Lee, Y.H. and H. Kim. 2011. Response of soil microbial communities to different farming systems for upland soybean cultivation. J. Korean Soc. Appl. Biol. Chem. 54:423-433.

Lee, Y.H. and H.D. Yun. 2011. Changes in microbial community of agricultural soils subjected to organic farming system in Korean paddy fields with no-till management. J. Korean Soc. Appl. Biol. Chem. 54:434-441.

Lee, Y.H. and S.K. Ha. 2011 a. Impacts of chemical properties on microbial population from upland soils in Gyeongnam Province. Korean J. Soil Sci. Fert. 44:242-247.

Lee, Y.H. and S.K. Ha. 2011b. Impacts of topography on microbial community from upland soils in Gyeongnam Province. Korean J. Soil Sci. Fert. 44:485-491.

Lee, Y.H., B.K. Ahn, and Y.K. Sonn. 2011. Effects of electrical conductivity on the soil microbial community in a controled horticultural land for strawberry cultivation. Korean J. Soil Sci. Fert. 44:830-835.

Macalady, J.L., M.E. Fuller, and K.M. Scow. 1998. Effects of metam sodium fumigation on soil microbial activity and community structure. J. Environ. Qual. 27:54-63.

Mechri, B., H. Chehab, F. Attia, F.B. Mariem, M. Braham, and M. Hammami. 2010. Olive mill wastewater effects on the microbial communities as studied in the field of olive trees by analysis of fatty acid signatures. Eur. J. Soil Bio. 146:312-318.

NIAST (National Institute of Agricultural Science and Technology). 2010a. Methods of soil chemical analysis. Suwon, Korea.

NIAST (National Institute of Agricultural Science and Technology). 2010b. Fertilizer recommendation for crops. Suwon, Korea.

Olsson, P.A., R. Francis, D.J. Read, and B. Söderström. 1998. Growth of arbuscular mycorrhizal mycelium in calcareous dune sand and its interaction with other soil micro-organisms 
as estimated by measurement of specific fatty acids. Plant Soil 201:9-16.

Rousk, J., P.C. Brookes, and E. Bååth. 2009. Contrasting soil pH effects on fungal and bacterial growth suggest functional redundancy in carbon mineralization. Appl. Environ. Microbiol. 75:1589-1596.

Rousk, J., E. Bååth, P.C. Brookes, C.L. Lauber, C. Lozupone, J.G. Caporaso, R. Knight, and N. Fierer. 2010. Soil bacterial and fungal communities across a $\mathrm{pH}$ gradient in an arable soil. ISME J. 4:1340-1351.
SAS Institute. 2006. SAS Version 9.1.3. SAS Inst., Cary, NC. Schutter, M.E. and R.P. Dick. 2000. Comparison of fatty acid methyl ester (FAME) methods for characterizing microbial communities. Soil Sci. Soc. Am. J. 64:1659-1668.

Yang, S.K., M.K. Kim, Y.W. Seo, K.J. Choi, S.T. Lee, Y.S. Kwak, and Y.H. Lee. 2012. Soil microbial community analysis of between no-till and tillage in a controlled horticultural field. World J. Microbiol. Biotechnol. 28:1797-1801.

Zelles, L. 1997. Phospholipid fatty acid profiles in selected members of soil microbial communities. Chemosphere 35:275-294. 